\title{
Activation of a low pH-dependent nuclease by apoptotic agents
}

\author{
Konrad S. Famulski ${ }^{\star, 1,2}$, Dawn Macdonald ${ }^{1}$, \\ Malcolm C. Paterson ${ }^{1,2}$ and Ewa Sikora ${ }^{3}$ \\ 1 Experimental Oncology Program, Cross Cancer Institute, Edmonton AB, T6G \\ 1Z2, Canada \\ 2 Department of Biological and Medical Research, King Faisal Specialist Hospital \\ and Research Centre, P.O. Box 3354, Riyadh 11211, Kingdom of Saudi Arabia \\ ${ }^{3}$ Department of Cellular Biochemistry, Nencki Institute of Experimental Biology, \\ Polish Academy of Sciences, Pasteura 3, Warsaw, 02 093, Poland \\ * corresponding author: Konrad S. Famulski, Department of Biological and \\ Medical Research (MBC 03), King Faisal Specialist Hospital and Research \\ Centre, P.O. Box 3354, Riyadh 11211, Kingdom of Saudi Arabia. \\ fax: 9661442 7858; e-mail: konrad@kfshrc.edu.sa
}

Received 10.3.98; revised 18.11.98; accepted 17.12 .98

Edited by B.A. Osborne

\begin{abstract}
Intracellular acidification caused by agents such as UV(C), etoposide or ceramide accompanies the progression of apoptosis. It is suggested that cellular acidosis may set favorable conditions for a dormant, low pH-dependent (acidic) nuclease, which could be involved in intranucleosomal genome degradation, a hallmark of programmed cell death. Here we show that exposure of HL-60 cells to acidotic/ apoptotic agents results in the several-fold activation of a novel low $\mathrm{pH}$-dependent (acidic) nuclease activity, as revealed by zymography. Its activity, which resides in nuclei, is associated with four polypeptides with apparent $M_{r}$ of 56,48 , 45 and $40 \mathrm{kDa}$. Treatment of HeLa cells with UV(C) or ceramide causes also the up-regulation of an acidic nuclease activity which is represented by 70 and $62 \mathrm{kDa}$ polypeptides. These observations suggest that acidic nuclease activation can be induced by the same apoptotic agents in different cell types. In HL-60 cells, acidic nuclease up-regulation triggered by acidotic agents follows the induction of AP-1 transcription factor active complexes and accompanies the progression of apoptosis. Inhibition of AP-1 factor activity caused by either anti-caspase/anti-acidotic agent $\mathrm{Zn}^{2+}$ or curcumin, an inhibitor of AP-1 binding to DNA and c-jun synthesis, protects cells from genome destruction. Acidic nuclease activation, however, is only partially inhibited by these factors. We propose that (i) the up-regulation of an acidic nuclease activity is governed by a regulatory pathway different from that responsible for AP-1 factor induction, caspases activation and intracellular acidification, and (ii) activation of an acidic nuclease does not cause any deleterious effects when AP-1 transcription factor induction, caspases activation and intracellular acidification are down-regulated. Thus, the acidic nuclease up-regulation alone is not a sufficient prerequisite for apoptosis.
\end{abstract}

Keywords: apoptosis; AP-1 transcription factor; ceramide; etoposide; low pH-dependent (acidic) nuclease; UV(C)

Abbreviations: EMSA, electrophoretic mobility shift assay; PMSF, phenylmethylsulfonyl fluoride; PBS, phosphate buffered saline

\section{Introduction}

Evidence that intracellular acidification is associated with the progression of apoptosis has been steadily accumulating. UV(C) irradiation, ${ }^{1}$ Fas receptor activtion, ${ }^{1}$ treatment with ceramide $^{1}$ or etoposide, ${ }^{2}$ growth factors withdrawal ${ }^{3,4}$ or protein kinase $\mathrm{C}$ inhibition ${ }^{5}$ all result in cellular acidosis, genome degradation and ensuing cell death. Inhibitors of isoprenylation, $\mathrm{Na}^{+} / \mathrm{H}^{+}$antiporter-mediated cytoplasmic $\mathrm{pH}$ homeostasis, ${ }^{6}$ V-type ATPase-catalyzed $\mathrm{H}^{+}$transport $^{7}$ or cystic fibrosis transmembrane regulator ${ }^{8}$ further complement the already impressive list of acidotic/apoptotic factors. It has been found that inhibition of apoptosis protects the genome from degradation and is accompanied by restoration of cytoplasmic $\mathrm{pH}$ to normal values. The range of factors, which protect cells from death and alleviate cellular acidosis, suggests that the onset of cellular acidification and apoptosis is controlled by intricate signal transduction pathway(s). Inhibition of apoptosis by reintroduction of growth factors, administration of PKc activators, ${ }^{6,9,10}$ overexpression of Bcl$2^{11,12}$ or Ha-ras ${ }^{13}$ suggest that cell survival depends strongly on pathways involving kinases Raf-1 and PKC. Direct quenching of the elevated cytoplasmic $\mathrm{H}^{+}$level also protects the genome from degradation and arrests cell death. ${ }^{1}$ The presence of $\mathrm{Zn}^{2+}$, inhibitors of ICE/CED3 death protease family ${ }^{12,14,15}$ or inhibitors of protein phosphatases ${ }^{16}$ all inhibit cellular acidification associated with programmed cell death. These observations suggest that cellular acidosis is regulated by upstream effectors such as phosphatases and caspases.

Acidotic/apoptotic agents such as UV(C) and ceramide $^{17,18}$ or growth factor withdrawal ${ }^{19}$ also induce the formation of active AP-1 transcription factor complexes. It is thought that AP-1 dimer or one of its components (e.g. c-jun) may be responsible for transcription regulation of genes involved in programmed cell death. ${ }^{17,18,20-25}$ Hence, it is conceivable that cellular acidification and AP-1 induction are governed by a common upstream acting element that regulates the procession of events participating in programmed cell death. Despite of the accumulated evidence pertaining to the importance of intracellular acidification in programmed cell death, there is no direct evidence for the involvement of a low $\mathrm{pH}$-dependent nuclease in this process. It has been postulated ${ }^{26-30}$ that decreased cellular $\mathrm{pH}$ sets permissive conditions for the manifestation of the activity of otherwise dormant DNAse II like $\mathrm{pH}$ dependent nuclease. Candidate $\mathrm{pH}$-dependent apoptotic nucleases can be divided into two classes distinguished by 
lower $30-37 \mathrm{kDa}^{27,30-33}$ or higher $56-70 \mathrm{kDa} \mathrm{M}_{\mathrm{r}}{ }^{34-36}$ The diversity of acidic nuclease forms may reflect tissue specificity, cell differentiation and, perhaps, different modes of post-translational modification. These forms were identified by the common property of activation by low $\mathrm{pH}$ in vitro, rather than by their direct involvement in apoptosis.

The relationship between intracellular acidification, AP1 factor induction and acidic nuclease activity has not yet been determined. We hypothesize that factor(s) responsible for acidification and the induction of AP-1 transcription factor may up-regulate the acidic nuclease activity in vivo and this effect should still be observed in vitro. In this report we investigated the effect of $U V(C)$, etoposide and ceramide treatment of $\mathrm{HL}-60$ cells on the activity of a low $\mathrm{pH}$-dependent nuclease. We found that these acidotic/apoptotic agents activate by several-fold an acidic nuclease which is different from DNAse II. This activation followed the induction of AP-1 transcription factor and was accompanied by genome degradation. Moreover, using inhibitors of cellular acidification or AP-1 DNA-binding activity we established that the up-regulation of the acidic nuclease activity takes place independently of AP-1 induction and intracellular acidification. Possible biological relevance of cellular acidification, AP-1 transcription factor induction and acidic nuclease up-regulation is discussed.

\section{Results}

The activation of a low-pH dependent nuclease by $\mathrm{U}(\mathrm{V}) \mathrm{C}$ coincides with the progression of apoptosis

Since UV radiation induces intracellular acidification ${ }^{1}$ and apoptosis $^{1,37,38}$ in Jurkat and HL-60 cells, we decided to investigate the relationship between the $U V(C)$-evoked apoptosis and the activity of a low pH-dependent (acidic) nuclease. The activity of an acidic nuclease present in nuclear extracts of cells undergoing apoptosis was analyzed by zymography. Low levels of acidic nuclease activity were observed in nuclear extracts isolated from untreated HL-60 cells (Figure 1, left panel, lane $\mathrm{C}$ ).

By $2 \mathrm{~h}$ post irradiation nuclease activity was readily detected. At $4 \mathrm{~h}$ post irradiation nuclease activity had increased reaching a maximal level at $8 \mathrm{~h}$ post treatment (Figure 1, left panel, lanes 4 and 8). Based on FACS analysis $36 \%$ of cells had degraded DNA (as indicated by subdiploid DNA content) $4 \mathrm{~h}$ post UV(C) and this number increased to $50 \%$ during next $4 \mathrm{~h}$ (Table 1). Together, these observations suggest that nuclease activation accompanies genome degradation. The acidic nuclease, detected in HL-60 cells upon activation by $\mathrm{U}(\mathrm{V}) \mathrm{C}$ irradiation, is represented by four polypeptides of apparent molecular weight $\left(M_{r}\right) 56,48,45$ and $40 \mathrm{kDa}$, as revealed by SDS-PAGE (Figure 1). The intensity of bands, which

\section{$\mathbf{U V}(\mathbf{C})$}
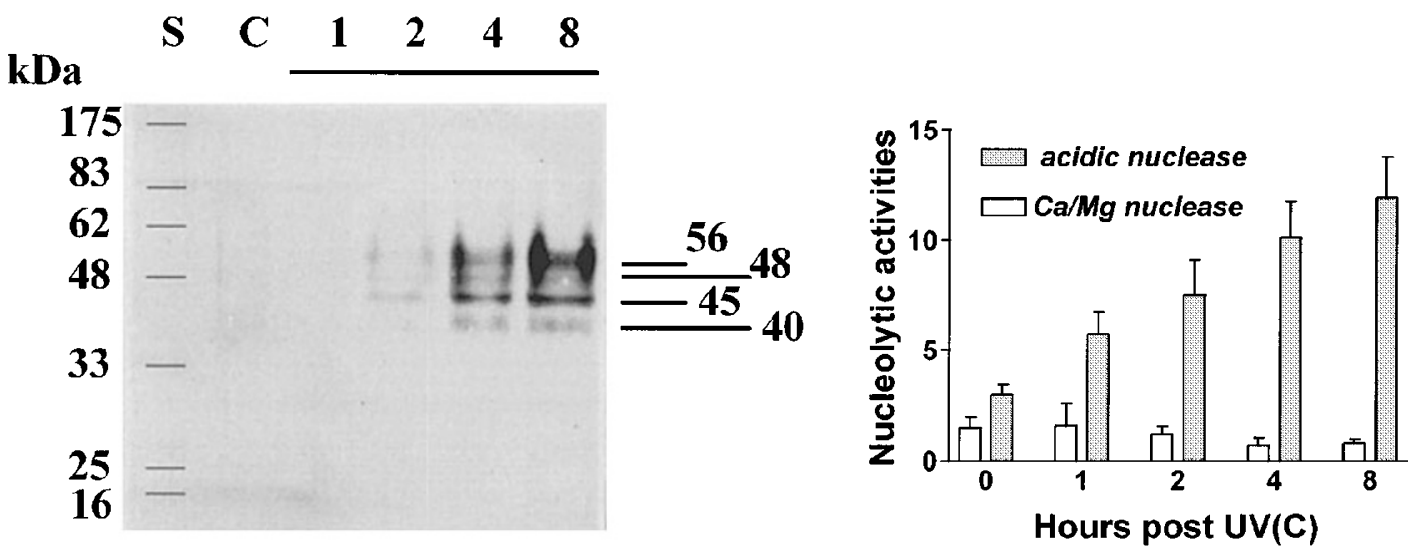

Figure 1 Nucleolytic activities in nuclear extracts isolated from UV(C)-irradiated HL-60 cells. Left panel: zymography carried out at pH 5.2. Lane S, molecular weight standards; lane $\mathrm{C}$, extract from unirradiated cells; lanes 1-8 $\mathrm{h}$ post irradiation. Right panel: digestion of calf thymus DNA (for details see Materials and Methods). The means \pm S.E. of three experiments are presented

Table 1 UV(C), etoposide and ceramide-induced apoptosis in HL-60 cells

\begin{tabular}{|c|c|c|c|c|c|c|}
\hline Hours & UV (C) & UV (C)+Zn & Etoposide & Etoposide+Zn & Ceramide & Ceramide+curcumin \\
\hline 1 & $1.2 \pm 0.2$ & $0.6 \pm 0.05$ & $0.8 \pm 0.3$ & $0.8 \pm 0.1$ & $4.5 \pm 1.1$ & $1.2 \pm 0.2$ \\
\hline 2 & $6.8 \pm 2.1$ & $0.5 \pm 0.3$ & $3.5 \pm 0.8$ & $0.8 \pm 0.3$ & $11.2 \pm 3.1$ & $1.8 \pm 0.5$ \\
\hline 4 & $36.7 \pm 8.1$ & $1.0 \pm 0.5$ & $30.6 \pm 5.2$ & $0.4 \pm 0.2$ & $46.2 \pm 7.5$ & $1.6 \pm 0.3$ \\
\hline 8 & $50.6 \pm 3.9$ & $2.3 \pm 1.3$ & $43.4 \pm 4.3$ & $2.9 \pm 1.1$ & $70.1 \pm 8.2$ & $5.3 \pm 1.2$ \\
\hline
\end{tabular}

The extent of apoptosis is shown as the percentage of cells that exhibit subdiploid DNA content. Mean values of at least three experiments are shown. The percentage of control cells with subdiploid DNA content was less than $1 \%$ 
appeared on zymographs, was time-, temperature- and $\mathrm{pH}$ dependent. Bands became visible when gels were incubated for $16-22 \mathrm{~h}$ at acidic $\mathrm{pH}$ but not at $\mathrm{pH} 7.5$, regardless of the presence or absence of $\mathrm{Ca}$ and $\mathrm{Mg}$ ions. Increase in the incubation temperature from $20-37^{\circ} \mathrm{C}$ substantially accelerated bands appearance at low $\mathrm{pH}$ but not at high $\mathrm{pH}$. Nucleolytic activity that was associated with $56-40 \mathrm{kDa}$ bands has been also verified by autoradiography. On the basis of these observations, we conclude that 56, 48, 45 and $40 \mathrm{kDa}$ polypeptides represent the acidic nuclease activity rather than different DNA-binding proteins. As this nuclease differs in both immunological properties $^{39}$ (Famulski et al, manuscript in preparation) and size from the well known acidic nuclease - DNAse II, ${ }^{40}$ we postulate that the nuclease monitored here represents a novel enzyme. It has been shown that in HL-60 cells an acidic nuclease but not a $\mathrm{Ca}^{2+} / \mathrm{Mg}^{2+}$-dependent nuclease is associated with the majority of the nucleolytic activity. ${ }^{38}$ To confirm that, we measured deoxyribonuclease activities present in nuclear extracts. To this end, extracts obtained from UV(C)-treated cells were tested for their propensity to digest high molecular weight calf thymus DNA and the reaction product i.e. acid-soluble oligonucleotides were detected by spectrophotometry. Figure 1 (right panel) shows that UV(C) irradiation caused up to a 6-fold increase in the low $\mathrm{pH}$-dependent $(\mathrm{pH} 5.2)$ nucleolytic activity. No significant changes in DNA digestion were found, however, when the same extracts were tested under conditions of higher $\mathrm{pH}$ (7.5) and in the presence of $\mathrm{Ca}$ and $\mathrm{Mg}$ ions. This means that the acidic nuclease rather than $\mathrm{Ca}^{2+} / \mathrm{Mg}^{2+}$-dependent nuclease activity is up-regulated by $\mathrm{UV}(\mathrm{C})$ in HL-60 cells.

\section{The effect of $\mathrm{Zn}^{2+}$ on UV(C) or etoposide-evoked AP-1 induction, apoptosis and acidic nuclease activation}

AP-1 transcription factor has been shown to have multiple functions in cellular processes such as proliferation, differentiation and apoptosis. ${ }^{41}$ As we noted before, factors that cause cellular acidosis are also known for their propensity to induce AP-1. If intracellular acidification, AP1 induction and nuclease activation are controlled during apoptosis by a common upstream regulator, an inhibitor of apoptosis should down-regulate the formation of AP-1 active complexes, prevent genome destruction and counteract the activation of the acidic nuclease. Hence, we examined the possibility that the appearance of low $\mathrm{pH}$-dependent nuclease active forms may be related to the indication of active AP-1 complexes. Nuclear extracts obtained from the UV(C) or etoposide-treated HL-60 cells were analyzed for the presence of AP-1 by electrophoretic mobility shift assay (EMSA), using a radioactively labeled double-stranded oligonucleotide containing the AP-1 binding sequence as a probe. As expected, the EMSA showed that UV(C) irradiation caused the induction of active AP-1 complexes (Figure 2, left panel).

Densitometric analysis of EMSA autoradiographs indicated that $39 \%$ of maximal induction took place during the first hour. The peak of induction (100\%) was observed within $4 \mathrm{~h}$ and was followed by a 4 -fold decrease at $8 \mathrm{~h}$ post-irradiation. Three independent experiments gave similar results. Exposure of cells to etoposide invariably led to maximal induction of AP-1 within $2 \mathrm{~h}$ (Figure 3 , left panel) as was observed in four independent experiments.

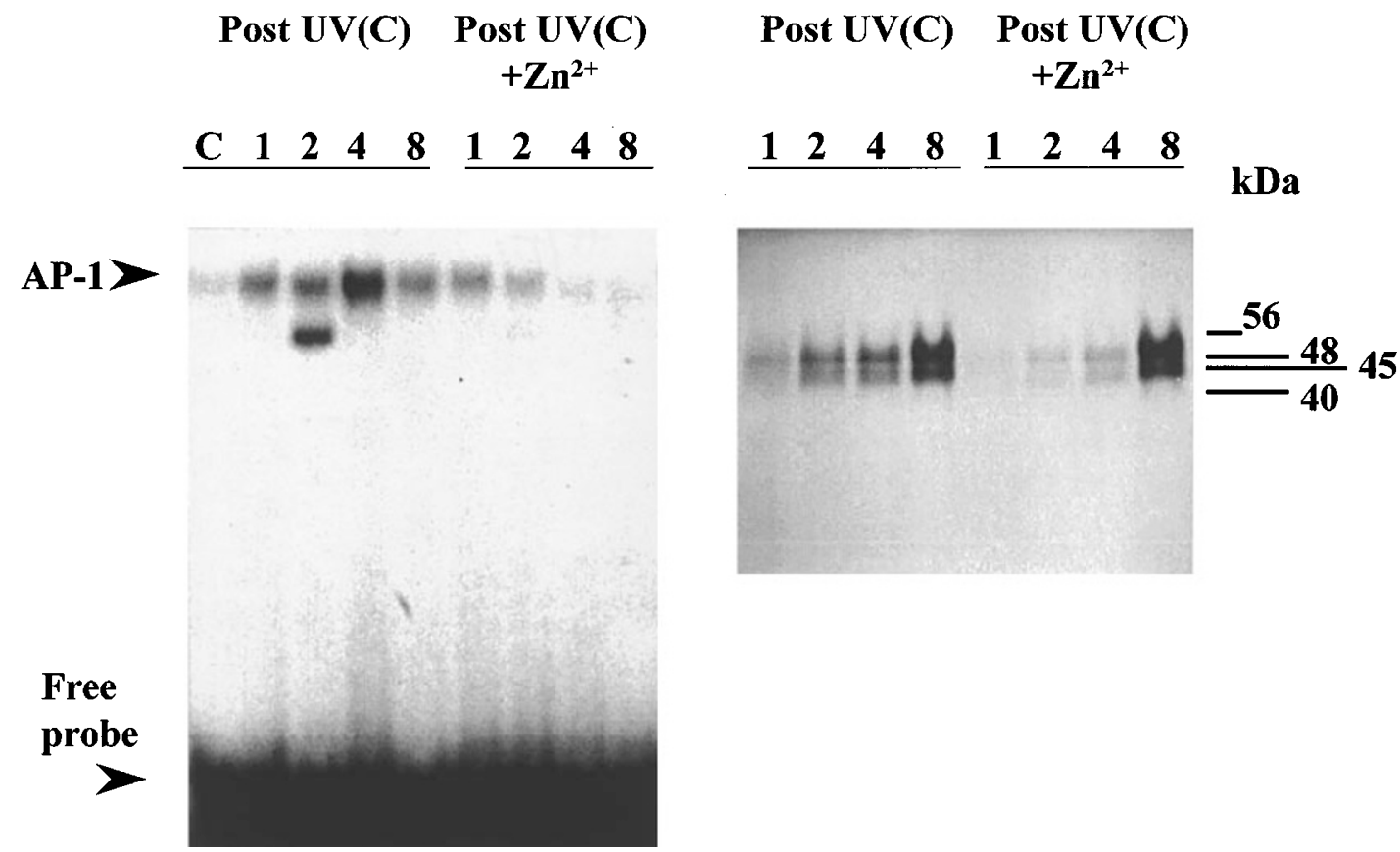

Figure 2 Induction of AP-1 and activation of a low pH-dependent nuclease by UV(C). Left panel: electrophoretic mobility shift assay of AP-1. Lane C, control; lanes $1-8 \mathrm{~h}$ post irradiation. Right panel: zymography carried out at $\mathrm{pH}$ 5.2. Lanes $1-8 \mathrm{~h}$ post irradiation 


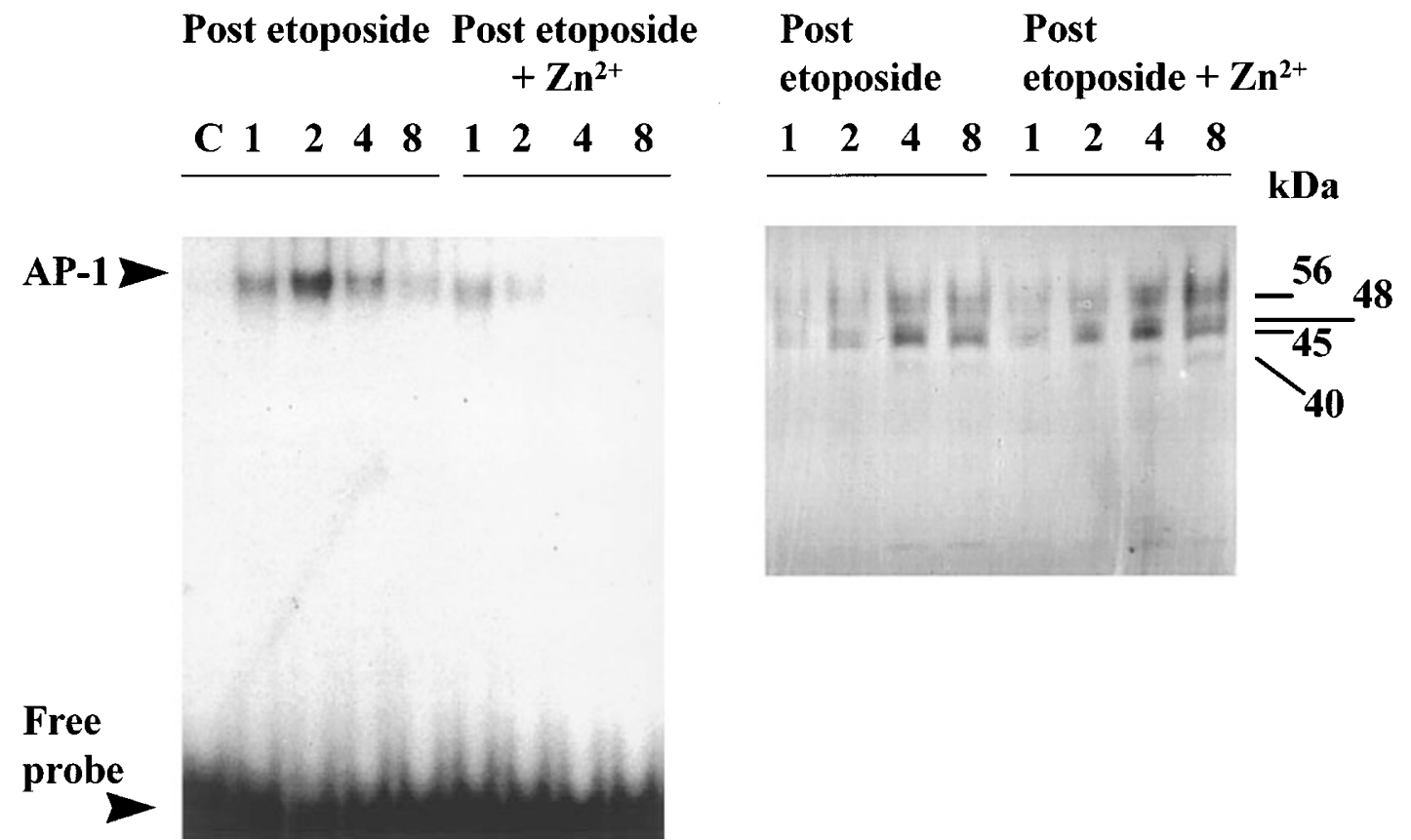

Figure 3 Induction of AP-1 and activation of a low pH-dependent nuclease by etoposide. Left panel: electrophoretic mobility shift assay of AP-1. Lane C, control; lanes 1-8 h post etoposide treatment. Right panel: zymography carried out at $\mathrm{pH}$ 5.2. Lanes $1-8 \mathrm{~h}$ post etoposide treatment

It has been reported that $\mathrm{Zn}^{2+}$ administration protects cells from UV or etoposide-evoked apoptosis ${ }^{14,37}$ and prevents intracellular acidification ${ }^{14}$ by inhibiting caspase 3 activation. ${ }^{42}$ In this study we examined the effect of $\mathrm{Zn}^{2+}$ administration on the formation of active AP-1 complexes and progression of apoptosis in $U V(C)$ or etoposide-treated $\mathrm{HL}-60$ cells. Treatment of $\mathrm{UV}(\mathrm{C})$ irradiated cells with $\mathrm{Zn}^{2+}$ resulted in the inhibition of AP-1 binding activity (Figure 2, left panel), with only $17 \%$ of maximal activity observed during the first hour, $4 \%$ during the next hour and no binding noted after $4 \mathrm{~h}$ post irradiation. The presence of $\mathrm{Zn}^{2+}$ effectively countered etoposide-evoked formation of active AP-1 complexes, with only $5 \%$ of maximal DNA binding activity observed within $2 \mathrm{~h}$ post-etoposide and no activity detected after $4 \mathrm{~h}$ (Figure 3, left panel).

Cells displaying subdiploid DNA content were apparent during $2 \mathrm{~h}$ post $\mathrm{UV}(\mathrm{C})$ or post etoposide treatment. However, number of these cells did not exceed $7 \%$ of the total population (Table 1). Intracellular DNA degradation accelerated during next $2 \mathrm{~h}(30-36 \%)$ and became a prominent feature of the cultures after $8 \mathrm{~h}$, when $40-50 \%$ of cells displayed subdiploid DNA content. In the presence of $\mathrm{Zn}$ ions, however, the number of cells with subdiploid DNA content was less than $3 \%$ at $8 \mathrm{~h}$ post treatment regardless of the apoptotic agent used. These data suggest that $U V(C)$ or etoposide-induced formation of active AP-1 complexes preceded DNA degradation, while $\mathrm{Zn}^{2+}$ administration prevented the activation of $\mathrm{AP}-1$ transcription factor and protected HL-60 cells from apoptosis.

Much to our surprise, however, administration of $\mathrm{Zn}$ ions did not fully inhibit the acidic nuclease activation caused by
$\mathrm{UV}(\mathrm{C})$. As shown in Figure 2 (right panel) $\mathrm{Zn}^{2+}$ only partially inhibited nuclease up-regulation during first $4 \mathrm{~h}$ post irradiation and had no effect on the nuclease activity after $8 \mathrm{~h}$ post treatment. Exposure of cells to etoposide also resulted in the activation of a low $\mathrm{pH}$-dependent nuclease and the kinetics of the nuclease activity up-regulation was similar to that observed for UV(C) (Figure 3, right panel). Acidic nuclease activity, however, remained high even after administration of $\mathrm{Zn}^{2+}$ and rescue from apoptosis. Of note, no up-regulation of the $\mathrm{Ca}^{2+} / \mathrm{Mg}^{2+}$-dependent nucleolytic activity was detected in etoposide-treated cells by either zymography or the direct measurement of DNA digestion. Analysis of the data presented above led us to the following conclusions (i) acidotic/apoptotic agents induce the formation of AP-1 active complexes and up-regulate acidic nuclease activity, (ii) the appearance of these complexes precedes genome degradation, (iii) nuclease activity upregulation follows the induction of AP-1 but is still increased even after AP-1 de-regulation and (iv) $\mathrm{Zn}^{2+}$ ions inhibit AP1 induction and apoptosis but not the activation of a low $\mathrm{pH}$-dependent nuclease. Hence AP-1 and caspase 3 activation is not required for the nuclease up-regulation.

\section{The effect of exogenous ceramide on AP-1 induction, apoptosis and acidic nuclease activation}

Ceramide is thought to be a key signaling molecule involved in the regulation of apoptotic and stress-related pathways. ${ }^{43,44}$ Since the apoptotic action of ceramide in HL-60 cells has been well documented, ${ }^{10,18}$ we examined its impact on the activity of a low $\mathrm{pH}$-dependent nuclease in vivo, in conjunction 
with AP-1 induction. Figure 4 (left panel) shows that the continuous exposure of HL-60 cells to exogenous ceramide caused a rapid and sustained induction of active AP-1 complexes.

Maximal induction was already observed within $1 \mathrm{~h}$ and the number of active complexes declined only to 66 and $64 \%$ after 2 and $4 \mathrm{~h}$, respectively. A substantial number of active AP- 1 complexes (33\% of the maximal level) were still present after $8 \mathrm{~h}$ of ceramide treatment. This observation confirms the kinetics of AP-1 induction by ceramide that have been recently reported by others. ${ }^{18}$ Curcumin, a pigment derived from the spice tumeric, was reported to counteract ceramide-evoked AP-1 activation and apoptosis in HL-60 cells, ${ }^{18}$ probably due to a direct interaction of this pigment with AP-1 binding to its DNA binding motif. ${ }^{45}$ We confirmed that the administration of curcumin strongly inhibits the activity of AP-1 in ceramide-treated cells (Figure 4, left panel). Only 11 and $9 \%$ of maximal DNAbinding activity was observed within 1 and $2 \mathrm{~h}$ respectively and no such activity was observed after 4 and $8 \mathrm{~h}$.

Ceramide rapidly induced genome degradation, which is consistent with its role as an apoptotic second messenger. After $2 \mathrm{~h}, 11 \%$ of ceramide-treated cells displayed subdiploid DNA content. This subpopulation increased to $46 \%$ during the next $2 \mathrm{~h}$ and to $70 \%$ of cells were affected after $8 \mathrm{~h}$ (Table 1). Pretreatment of cells with curcumin rescued them from ceramide-evoked apoptosis (Table 1). It has been reported, ${ }^{46}$ however, that prolonged incubation of HL-60 cells with curcumin, in the absence of serum factors, leads to cell death. In our hands, curcumin alone did not cause deleterious effects in HL-60 cells within the time frame studied ( $5 \%$ subdiploid cell count after $8 \mathrm{~h}$ ).
We found, that ceramide is also a potent activator of the acidic nuclease in vivo. Figure 4 (right panel) shows appreciable activity of a low $\mathrm{pH}$-dependent nuclease was observed during the first $2 \mathrm{~h}$ of ceramide treatment. This activity increased steadily during the next $6 \mathrm{~h}$. The kinetics of nuclease activation by ceramide was very similar to that observed for genome degradation. We did not find, however that the $\mathrm{Ca}^{2+} / \mathrm{Mg}^{2+}$-dependent nucleolytic activity was up-regulated by ceramide administration. Curcumin, which counteracted ceramide-evoked apoptosis, strongly inhibited nuclease activity within the first $4 \mathrm{~h}$ but by $8 \mathrm{~h}$ was much less effective. The time course of curcumin downregulation of nuclease activity in ceramide-treated cells may suggest that curcumin offsets rather than inhibits nuclease activation. Similar results were obtained when curcuminpretreated cell cultures were exposed to UV(C) irradiation. AP-1 activity was greatly diminished while nuclease activation was inhibited only during first $4 \mathrm{~h}$ post treatment (not shown).

\section{Activation of a low pH-dependent nuclease in HeLa cells}

In Figures 1-4 we documented that three acidotic/apoptotic agents namely, UV(C), etoposide and ceramide caused the activation of a novel acidic nuclease in HL-60 cells (Figures $1-4)$. Next we asked whether this phenomenon is limited to $\mathrm{HL}-60$ cells or can be demonstrated in other cell types. We therefore repeated these experiments using near confluent cultures of HeLa cells treated with apoptotic agents. Total cell extracts were obtained and analyzed by zymography after $4 \mathrm{~h}$.

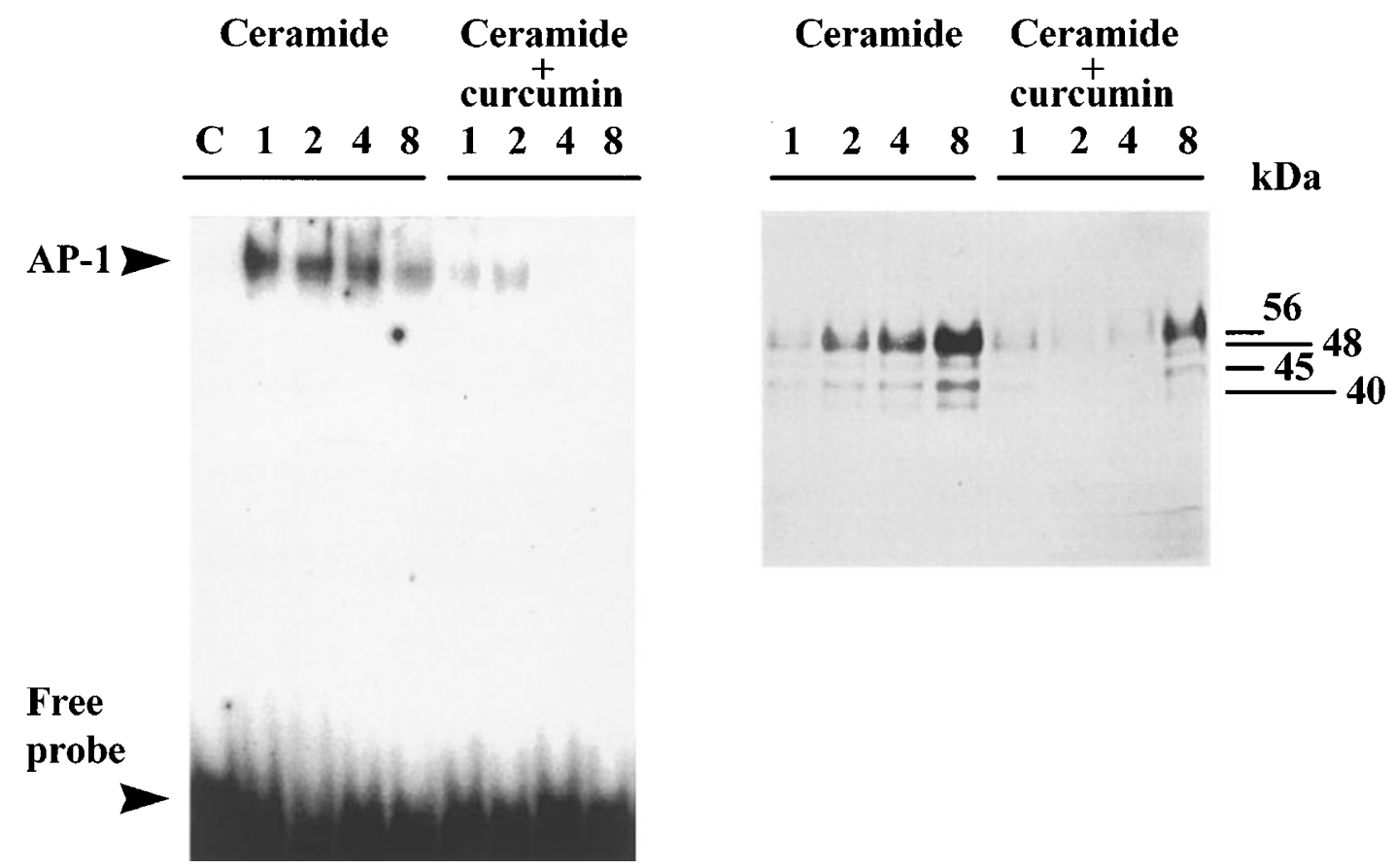

Figure 4 Induction of AP-1 and activation of a low pH-dependent nuclease by ceramide. Left panel: electrophoretic mobility shift assay of AP-1. Lane C, control; lanes $1-8 \mathrm{~h}$ of incubation with ceramide. Right panel: zymography carried out at $\mathrm{pH} 5.2$. Lanes $1-8 \mathrm{~h}$ of incubation with ceramide 


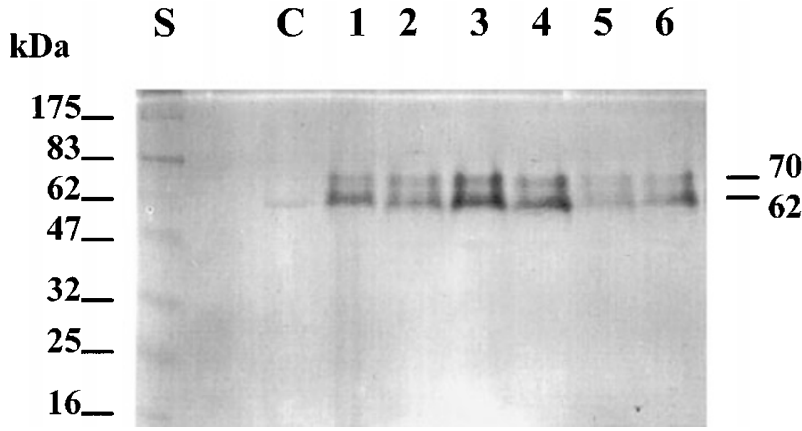

Figure 5 Zymography of an acidic nuclease present in total extracts obtained from UV(C) or ceramide-treated HeLa cells. Lane S, molecular weight standards; lane $\mathrm{C}$, control extract; lane $1,4 \mathrm{~h}$ after UV(C) irradiation; lane $2,4 \mathrm{~h}$ after serum withdrawal; lane $3,4 \mathrm{~h}$ of incubation with ceramide; lane 4 , ceramide and $\mathrm{Zn}^{2+}$ coincubation; lane 5 , ceramide and curcumin; lane $6,4 \mathrm{~h}$ of incubation with $\mathrm{Zn}^{2+}$ after UV(C) irradiation

Untreated HeLa cells exhibited low activity of the acidic nuclease which was represented by the $62 \mathrm{kDa}$ polypeptide (Figure 5, lane C). Serum withdrawal or UV(C) irradiation resulted in the substantial activation of this nuclease and caused the appearance of a novel $70 \mathrm{kDa}$ form (Figure 5, lanes 1 and 2). Administration of ceramide caused the most efficient activation of the nucleolytic activity represented by the 62 and $70 \mathrm{kDa}$ polypeptides (Figure 5, lane 3). Similar results were obtained when nuclear extracts, isolated from treated HeLa cells, were examined. Pre-treatment of HeLa cells with curcumin strongly inhibited the ceramide-evoked activation of both polypeptides (Figure 5, lane 5), whereas the administration of $\mathrm{Zn}^{2+}$ was much less effective (Figure 5 , lane 4). Nuclease activation, caused by UV(C) irradiation was only partially alleviated by $\mathrm{Zn}$ ions (Figure 5, lane 6). This experiment clearly demonstrated that HeLa cells possess a low $\mathrm{pH}$-dependent nuclease whose activity is up-regulated by acidotic/apoptotic agents and can be, at least partially, down-regulated by anti-apoptotic agents.

\section{Discussion}

Our study sought to establish the relationship between the progression of apoptosis and the regulation of a low $\mathrm{pH}$ dependent (acidic) nuclease. Apoptosis is a natural mechanism whereby unwanted, sick or DNA-damaged cells are eliminated. ${ }^{47}$ Ordained destruction of the genome, which is manifested by the intranucleosomal cleavage of chromatin, is considered a hallmark of apoptosis. The resulting DNA ladder is generally believed to result from activation of endogenous nuclease(s). ${ }^{48}$ Apoptotic nucleases are expected to fulfill certain criteria. For example a candidate enzyme must be dormant or absent in living cells. After the initiation of apoptosis, its activity should increase either in response to altered intracellular milieu (e.g. increased intracellular $\mathrm{Ca}^{2+}$ level), increased protein expression or post-translational modifications. ${ }^{49,50}$ Activation of certain nucleases in response to the initiation of apoptosis was in fact observed during $T$ cell receptor-mediated cell death of $T$ cell hybridomas and thymocytes, ${ }^{51}$ interleukin-2 deprivation of cytotoxic T-lymphocytes, ${ }^{52}$ administration of angiotensin II to ventricular myocytes, ${ }^{53}$ elimination of prostate epithelial cells caused by androgen ablation ${ }^{54}$ or activation of Fas receptor in Jurkat cells. ${ }^{55}$ Administration of anti-apoptotic agents inhibited nucleolytic activities. $\mathrm{Ca}^{2+} / \mathrm{Mg}^{2+}$ dependence, $\mathrm{pH}$ optimum above 7 and inhibition in vitro by $\mathrm{Zn}^{2+}$ were the characteristic features of nucleases that have been identified by these studies. These features lent credence to the idea that genome degradation and ensuing cell death are regulated by $\mathrm{Ca}^{2+}$-dependent mechanisms. Nonetheless, cells may destroy their genome and die in the absence of $\mathrm{Ca}^{2+}$ signal. As we noted earlier, apoptotic agents can cause intracellular acidification and genome degradation without changing the intracellular $\mathrm{Ca}^{2+}$ concentration. ${ }^{2,14}$ Apoptosis of Jurkat cells caused by UV(C), exogenous ceramide or Fas receptor activation could be prevented by direct buffering of the acidic $\mathrm{pH}$ in the cytoplasm. ${ }^{1}$ It had been thus inferred that cellular acidosis was providing favorable reaction conditions for the otherwise dormant low $\mathrm{pH}$-dependent nuclease(s), which could perform the role of an apoptotic nuclease. ${ }^{26-30}$ This class of deoxyribonucleases, whose generic representative is DNAse II, is characterized by (i) the dependence on acidic $(<7) \mathrm{pH}$ that is necessary for the nucleolytic activity, (ii) lack of stimulation by $\mathrm{Ca}$ and $\mathrm{Mg}$ ions and (iii) insensitivity to the inhibitory action of $\mathrm{Zn}$ ions in vitro. One would predict that this putative apoptotic nuclease should exhibit same activity in extracts isolated from control and apoptotic cells, since liabilities to intracellular $\mathrm{pH}$ should be observed only in vivo. As we have shown, this was not the case. The acidic nuclease activity was present in the nuclear fraction of untreated cells at a very low level while acidotic/apoptotic agents caused substantial activation of this enzyme. Whether the upregulation of nuclease activity results from post-translational modifications or increased protein level remains to be established. Nuclease active forms, as revealed by zymography, are represented in HL-60 cells by four polypeptides of 56, 48, 45 and $40 \mathrm{kDa} \mathrm{M}_{\mathrm{r}}$. HeLa cells, on the other hand, possess 62 and $70 \mathrm{kDa}$ forms of the acidic nuclease. Since the up-regulation of a low $\mathrm{pH}$-dependent nuclease activity by apoptotic agents is not restricted to a particular cell line, it may therefore represent a more general event. Of note, anoxia also results in the up-regulation of a low $\mathrm{pH}$-dependent nuclease in fibroblasts which is represented by DNAse II-like 29-31 kDa polypeptides and a novel $44 \mathrm{kDa}$ polypeptide. ${ }^{56}$

Our enzyme is different from DNAse II, as judged by its apparent molecular weight, although certainly belongs to the class of low $\mathrm{pH}$-dependent nucleases. We have recently purified a $60 \mathrm{kDa}$ acidic nuclease from human liver and skin fibroblasts that is clearly different from DNAse II but similar to $56 \mathrm{kDa}$ form found in HL-60 cells $^{39}$ (Famulski et al, manuscript in preparation). The diversity of active polypeptides representing this novel nuclease may reflect the cell type specificity and/or posttranslational modifications. ${ }^{57}$

The time course of nuclease activation in HL-60 cells shows good temporal correlation with the progression of apoptosis. Acidic nuclease activity usually reached its maximum within 4-8 $\mathrm{h}$ post treatment. At that time the population of subdiploid cells accounted for $30-70 \%$ of 
total cell count. We therefore conclude that $U V(C)$, etoposide or ceramide-induced genome degradation may be caused by low pH-dependent nuclease activity. Moreover, it has been extensively documented that cell death is preceded and then accompanied by the appearance of acidified cells. Exposure to acidotic/apoptotic agents results in $12-20 \%$ of cells succumbing to acidosis within $2 \mathrm{~h}$. This number increases to $51-70 \%$ after 4 h. ${ }^{1,12,14,15,42}$ Hence, we suggest that the nuclease activation and the decrease in cellular $\mathrm{pH}$ occur simultaneously. However, nuclease upregulation alone does not cause deleterious effects to the cell. Our findings demonstrate that anti-caspase/antiacidotic agent $\mathrm{Zn}^{2+}$ rescues cells from genome degradation but does not alleviate the nuclease up-regulation. A similar conclusion can be reached when the effect of curcumin, an inhibitor of AP-1 transcription factor activity and apoptosis ${ }^{18,25,45}$ is evaluated. This drug rescues cells from being killed by ceramide and appears to offset rather than inhibit the ceramide-evoked acidic nuclease upregulation. Clearly, the acidic nuclease which resides in HL-60 cells and constitutes the major nucleolytic activity therein $^{38}$ (this paper), is activated by acidotic/apoptotic agents in vivo. However, the mechanism down-regulating its activity remains to be established. It is conceivable that overexpression of anti-apoptotic proteins such as Bcl-2 or Ha-ras rather than $\mathrm{Zn}^{2+}$ or curcumin administration will alleviate the nuclease up-regulation caused by acidotic/ apoptotic agents. ${ }^{13,52}$ Since activation of an acidic nuclease does not cause any deleterious effects when AP-1 transcription factor activity, caspase activation and intracelIular acidification are down-regulated, we postulate that the acidic nuclease up-regulation alone is not a sufficient prerequisite for the execution of apoptosis.

Recently a novel mechanism responsible for the activation of a death nuclease has been discovered. The nuclease, $C A D,{ }^{58}$ is present in living cells as an inactive complex with its inhibitor ICAD. Caspases activated by apoptotic stimuli cleave ICAD, thus allowing CAD to degrade chromosomal DNA. ${ }^{59}$ Hence, apart from the postulated role of acidification and acidic nucleases in cellular death, a caspase-involving pathway that leads to genome degradation is being now considered. This pathway may be responsible for the progression of apoptosis occurring independently of cellular acidosis.

As alluded to before, the AP-1 transcription factor is associated with the initiation of apoptosis in HL-60 cells. We show here that the formation of its active complexes, induced by acidotic agents [UV(C), etoposide and ceramide], precedes apoptosis. Inhibition of AP-1, caused by the anti-caspase/anti-acidotic agent $\mathrm{Zn}^{2+14,42}$ or by curcumin, an inhibitor of $\mathrm{AP}-1$ and $\mathrm{NF} \kappa \mathrm{B}$-dependent gene expression, ${ }^{45}$ invariably led to the protection of cells from apoptosis. It has been recently documented that suppression of AP-1 activity by curcumin results from the inhibition of c-jun synthesis. ${ }^{25}$ The role of c-jun, a component of dimers constituting AP-1 transcription factor, in the initiation of apoptosis is being now postulated. Increased c-jun expression apparently leads to the formation of AP-1 homodimers and induces apoptosis. ${ }^{20,25}$ It has been also demonstrated that $c$-jun acts upstream of the ICE/CED-3 family of cysteine proteases. ${ }^{20} \mathrm{Zn}^{2+}$ has been found to prevent the induction of active AP-1 complexes (this paper), activation of caspase $-3^{42}$ while the caspase inhibitor alleviates acidification. ${ }^{12,15}$ Based upon these observations, we postulate that AP-1 induction, caspase activation and cellular acidification are in the same signaling pathway that is responsible for the initiation and progression of apoptosis. This pathway comprises $\mathrm{Zn}^{2+}$-sensitive element(s) regulating AP-1 induction, caspase activation and ensuing acidification, while another pathway regulates the activity of a low pH-dependent nuclease and consists of $\mathrm{Zn}^{2+}$-insensitive element(s).

\section{Materials and Methods}

\section{Cell culture and treatment}

HL-60 cells were maintained in Ham's F12 medium containing $10 \%$ fetal calf serum. Cells were grown to a density of $5 \times 10^{5} \mathrm{cells} / \mathrm{ml}$ and a total of $23 \times 10^{6}$ cells were washed and resuspended in $0.2 \mathrm{ml}$ of phosphate-buffered saline (PBS), placed in a large culture dish and exposed to UV(C) light $(254 \mathrm{~nm})$ to a cumulative dose of $20 \mathrm{~J} / \mathrm{m}^{2}$. Total exposure time was $20 \mathrm{~s}$. Immediately after irradiation, $40 \mathrm{ml}$ of pre-warmed complete medium supplemented with $1 \mathrm{mM}$ zinc sulfate was added to the cells. At various times post-irradiation $(0-8 \mathrm{~h})$ cells were collected for flow cytometric analysis of DNA content and isolation of nuclear proteins. Prior to etoposide treatment $23 \times 10^{6}$ cells were resuspended in $23 \mathrm{ml}$ complete medium then incubated with the drug (20 $\mu \mathrm{g} / \mathrm{ml}$, Sigma-Aldrich Canada Ltd., Oakville, ON) for $30 \mathrm{~min}$, after which cells were washed with complete medium and resuspended in the same volume of $\mathrm{ZnSO}_{4}$-containing medium. At various times post-treatment $(0-8 \mathrm{~h})$ cells were collected for flow cytometric analysis of DNA content and isolation of nuclear proteins. For ceramide treatment, cells were incubated overnight in serum-free medium at a density $2 \times 10^{5}$ cells $/ \mathrm{ml}$. Ceramide ( $\mathrm{N}$-acetylsphingosine; Biomol Research Laboratories Inc, Plymouth Meeting, PA, USA) was added directly to the serum-free media at a final concentration of $10 \mu \mathrm{M}$. Ceramide-treated cells were rescued from apoptosis by the addition of $50 \mu \mathrm{M}$ curcumin (Boehringer Mannheim, Laval, PQ), $30 \mathrm{~min}$ before cultures were treated with ceramide. At various times after treatment $(0-8 \mathrm{~h})$, cells were collected for flow cytometric analysis of DNA content and isolation of nuclear proteins.

Near confluent HeLa cells, grown in Ham's F12 medium supplemented with $10 \%$ fetal calf serum, were treated with $10 \mu \mathrm{M}$ ceramide in serum-free medium. In some cases cells were pretreated with $50 \mu \mathrm{M}$ curcumin prior to ceramide administration or coincubated with ceramide and $1 \mathrm{mM} \mathrm{ZnSO}_{4} \mathrm{UV}(\mathrm{C})$ irradiation $\left(20 \mathrm{~J} / \mathrm{m}^{2}\right)$ was achieved by exposing cells growing on culture dishes to UV light as described above. After $4 \mathrm{~h}$ of incubation cells were collected in lysis buffer as described below.

\section{Nuclear extract preparation, electrophoretic mobility shift assay and zymography}

Nuclear extracts were obtained as described previously. ${ }^{23}$ Lysis buffer contained additionally $0.5 \mathrm{mM}$ phenylmethylsulfonyl fluoride (PMSF) and $10 \mu \mathrm{g} / \mathrm{ml}$ of pepstatin, aprotinin and leupeptin. The extracts were stored at $-70^{\circ} \mathrm{C}$. Protein content was measured with the Bradford reagent (BioRad Laboratories, Richmond, CA, USA). Five $\mu \mathrm{g}$ of nuclear proteins were assayed for the formation of active AP-1 complexes using a gel mobility-shift assay kit (Stratagene Cloning 
Systems, La Jolla, CA, USA). AP-1 consensus oligonucleotide (Stratagene) was $5^{\prime}$ labeled using polynucleotide kinase (Pharmacia Biotech Inc., Baie D'Urfe, PQ) and $\left[\gamma^{32}\right.$ P]ATP (NEN Research Laboratory Products, Boston MA, USA). Competition studies were performed by adding 50 -fold molar excess of unlabeled oligonucleotide to reaction mixtures. Samples were analyzed by nondenaturing gel electrophoresis ${ }^{60}$ and autoradiography. Autoradiographs that visualized EMSA assays were scanned by an IBM computer using a video camera. A digitized image analyzer (kindly provided by Dr. B. Palcic, BC Cancer Research Centre, Vancouver, BC) was then used to measure the intensity of the signals corresponding to AP-1 DNAbinding activity. Zymography assays were done according to ${ }^{34}$ with some modifications. Ten per cent Laemmli SDS-acrylamide gels were co-polymerized with calf thymus DNA $(0.2 \mathrm{mg} / \mathrm{ml})$ and stored overnight at $4^{\circ} \mathrm{C}$. Eighty $\mu \mathrm{g}$ of nuclear or total cellular protein were mixed with an equal volume of the sample buffer and separated at $100 \mathrm{mV}$ for $90 \mathrm{~min}$. After washing and renaturation of proteins, gels were incubated in the activation buffer $(50 \mathrm{mM}$ sodium acetate, $\mathrm{pH} 5.2,5 \mathrm{mM} \beta$-mercaptoethanol, $0.1 \%$ Triton X-100) overnight at room temperature. Acidic nuclease activity was detected by staining gels with ethidium bromide. Active polypeptides showed up as black bands on a fluorescent background. In order to determine the apparent molecular weight $\left(\mathrm{M}_{\mathrm{r}}\right)$ of acidic nuclease prestained standards (New England BioLabs Ltd., Mississauga, $\mathrm{ON}$ ) of known $\mathrm{M}_{\mathrm{r}}$ values were used.

\section{Total cell extract preparation and estimation of nucleolytic activity}

Cells $\left(4 \times 10^{6}\right)$ were lysed in $500 \mu \mathrm{l}$ of $100 \mathrm{nM}$ sodium acetate buffer pH 5.2 containing 1\% NP-40, $5 \mathrm{mM}$ 2-mercaptoethanol, $0.5 \mathrm{mM}$ PMSF and $10 \mu \mathrm{g} / \mathrm{ml}$ of pepstatin, aprotinin and leupeptin. After $15 \mathrm{~min}$ of incubation on ice, extracts were centrifuged at $4^{\circ} \mathrm{C}$ for $15 \mathrm{~min}$ at 14000 r.p.m. in Eppendorf microcentrifuge. Supernatants were immediately frozen and used for zymography within a few days.

For estimation of nucleolytic activity $10 \mu \mathrm{g}$ of extracted nuclear proteins were incubated in the reaction mixture (100 $\mu$ l final volume) consisting of either $50 \mathrm{mM}$ sodium acetate $\mathrm{pH} 5.2,1 \mathrm{mM} 2$ mercaptoethanol and $33 \mu \mathrm{g}$ of calf thymus DNA, or $50 \mathrm{mM}$ Tris-Cl $\mathrm{pH} 7.5,50 \mathrm{mM} \mathrm{NaCl}, 3 \mathrm{mM} \mathrm{CaCl}, 3 \mathrm{mM} \mathrm{MgCl} 2,1 \mathrm{mM}$ 2mercaptoethanol and $33 \mu \mathrm{g}$ of calf thymus DNA. Reactions (in duplicates) were carried out for $30 \mathrm{~min}$ and then terminated with the additon of $66 \mu \mathrm{l}$ of ice-cold $1.4 \mathrm{M}$ perchloric acid. After a brief incubation on ice, samples were centrifuged at $4^{\circ} \mathrm{C}$ for 6 min at 14000 r.p.m. in Eppendorf microcentrifuge. Absorbency at $260 \mathrm{~nm}$ was measured in $100 \mu \mathrm{l}$ aliquots with a Beckman diode-array spectrophotometer DU 7400. Measured values were corrected for nonspecific absorbency by residual detergent present in nuclear extracts. An activity unit was defined as the amount of enzyme, present in $1 \mathrm{mg}$ of protein extract, capable of release of 1 absorbency unit of acidsoluble oligonucleotides during $30 \mathrm{~min}$.

\section{Flow cytometric analysis of DNA content}

Cells were harvested by centrifugation, washed once with PBS and fixed in $70 \%$ ethanol overnight at $4{ }^{\circ} \mathrm{C}$. Fixed cells were stained in PBS conatining $50 \mu \mathrm{g} / \mathrm{ml}$ of propidium iodide and $0.1 \mathrm{mg} / \mathrm{ml}$ of RNAse (DNAse-free; Pharmacia Biotech Inc., Baie D'Urfe, PQ) for $30 \mathrm{~min}$. Analysis was performed within $30 \mathrm{~min}$ of staining. Fluorescence was detected with a FACSort cytometer (Becton-Dickinson, San Jose, CA, USA) equipped with a doublet discrimination module. Propidium iodide fluorescence was excited with an argon ion laser emitting at $488 \mathrm{~nm}$ and collected by a photomultiplier tube after passing through a $585 \mathrm{~nm}$ band pass filter. The same instrument settings were used for all experiments. Data were collected, using linear amplification for forward scatter, side scatter, and processed with CELLQuest Software (Becton-Dickinson, San Jose, CA, USA). Debris was excluded using forward and side scatter and a singlet gate was used in FL2-Width and FL2-Area dot plots.

\section{Acknowledgements}

This study was supported by MRC of Canada Grant No. MT-10079 (M.C.Paterson) and Samuel Gadeski Fund (E.Sikora). The Authors thank Dr. Roseline Godbout (Cross Cancer Institute, Edmonton, Canada) for the helpful comments.

\section{References}

1. Gottlieb RA, Nordberg J, SkowronskiE and BabiorM (1996) Apoptosis induced in Jurkat cells by several agents is preceded by intracellular acidification. Proc. Natl. Acad. Sci. USA 93: 654-658

2. Barry MA, Reylnods JE and Eastman A (1993) Etoposide-induced apoptosis in human HL-60 cells is associated with intracellular acidification. Cancer Res.53: 2349-2357

3. Li J and Eastman A (1995) Apoptosis in an interleukin-2-dependent cytotoxic T lymphocyte cell line is associated with intracellular acidification. J. Biol. Chem. 270: $3203-3211$

4. Rebollo A, Gomez J, Martinez de Aragon A, Lastres P, Silva A and Perez-Sala D (1995) Apoptosis induced by IL-2 withdrawal is associated with an intracellular acidification. Exp. Cell. Res. 218: 581-585

5. Caceres-Cortes J, Rajotte D, Dumouchel J, Haddad P and Hoang T (1994) Product of the steel locus suppresses apoptosis in hemopoetic cells. Comparison with pathways activated by granulocyte macrophage colonystimulating factor. J. Biol. Chem. 269: 12084-12091

6. Perez-Sala D, Collado-Escobar D and Mollinedo F (1995) Intracellular alkalinization suppresses lovastatin-induced apoptosis in $\mathrm{HL}-60$ cells through the inactivation of a pH-dependent endonuclease. J. Biol. Chem. 270: 62356242

7. Gottlieb RA, Giesing HA, Zhu JY, Engler RL and Babior BM (1995) Cell acidification in apoptosis: Granulocyte colony-stimulating factor delays programmed cell death in neutrophils by up-regulating the vacuolar $\mathrm{H}^{+}$. ATPase. Proc. Natl. Acad. Sci. USA 92: 5965-5968

8. Gottlieb RA and Dosanjh A (1996) Mutant cystic fibrosis transmembrane conductance regulator inhibits acidification and apoptosis in $\mathrm{C} 127$ cells: Possible relevance to cystic fibrosis. Proc. Natl. Acad. Sci. USA 93: 3587-3591

9. Rajotte D, Haddad P, Haman A, Cragoe JrEJ and Hoang T (1992) Role of protein kinase $\mathrm{C}$ and the $\mathrm{Na}^{+} / \mathrm{H}^{+}$antiporter in suppression of apoptosis by granulocyte macrophage colony-stimulating factor and interleukin-3. J. Biol. Chem. 267: 9980-9987

10. Jarvis WD, Fornari JR FA, Browning JL, Gerwitz DA, Kolesnick RN and Grant S (1994) Attenuation of ceramide-induced apoptosis by diglyceride in human myeloid leukemia cells. J. Biol. Chem. 269: 31685-31692

11. Reylnods JE, Li J, Graig RW and Eastman A (1996) BCL-2 and MCL-1 expression in chinese hamster ovary cells inhibits intracellular acidification and apoptosis induced by staurosporine. Exp. Cell Res. 225: 430-436

12. Meisenholder GW, Martin SJ, Green DR, Nordberg J, Babior BM and Gottlieb RA (1996) Events in apoptosis. Acidification is downstream of protease activation and bcl-2 protection. J. Biol. Chem. 271: 16260-16262

13. OstadM, ShuWP, Kong Land Liu BC-S(1996) Ha-ras oncogene abrogates apHdependent endonuclease activity of apoptosis in normal rat kidney. Cancer Lett. 98: $175-182$

14. Morana S, Li J, Springer EW and Eastman A (1994). The inhibition of etoposideinduced apoptosis by zinc is associated with modulation of intracellular $\mathrm{pH}$. Int. J. Oncol. 5: 153-158

15. Wolf CM, Reynolds JE, Morana SJ and Eastman A (1997) The temporal relationship between protein phosphatase, ICE/CED-3 proteases, intracellular acidification, and DNA fragmentation in apoptosis. Exp. Cell Res. 230: 22-27 
16. Morana SJ, Wolf CM, Li J, Reynolds JE, Brown MK and Eastman A (1996) The involvement of protein phosphatases in the activation of ICE/CED-3 protease, intracellular acidification, DNA digestion, and apoptosis. J. Biol. Chem. 271: $18263-18271$

17. Devary Y, Gottlieb RA, Lau LF and Karin M (1991) Rapid and preferential activation of the $c$-jun gene during the mammalian UV response. Moll. Cell. Biol. 11: $2804-2811$

18. Sawai H, Okazaki T, Yamamoto H, Okano H, Takeda Y, Tashima M, Sawada H, Okuma M, Ishikura H, Umehara H and Domae N (1995) Requirement of AP-1 for ceramide-induced apoptosis in human leukemia HL-60 cells. J. Biol. Chem. 270: $27326-27331$

19. Collota F, Polentarutti N, Sironi M and Mantovani A (1992) Expression and involvement of c-fos and c-jun protooncogens in programmed cell death induced by growth factor deprivation in lymphoid cell lines. J. Biol. Chem. 267: 1827818283

20. Bossy-Wetzel E, Bakiri L and Yaniv M (1997) Induction of apoptosis by the transcription factor C-Jun. EMBO J. 17: 1695-1709

21. Jehn BM and Osborne BA (1997) Gene regulation associated with apoptosis Crit. Rev. Eucaryot. Gene Expr. 7: 179-193

22. Schadendorf D, Kern MA, Artuc M, Pahl HL, Rosenbach T, Fichtner I, Nurnberg W, Stuting S, von StebutE, Worm M, Makki A, Jurgovsky K, Kolde G and Henz BM (1996) Treatment of melanoma cells with the synthetic retinoid CD437 induces apoptosis via activation of AP-1 in vitro, and causes growth inhibition in xenografts in vivo. J. Cell Biol. 135: 1889-1898

23. Sikora E, GrassilliE, BellesiaE, Troiano L and FranceschiC (1993) Studies of the relationship between cell proliferation and cell death. III. AP-1 DNA-binding activity during Concanavalin A-induced proliferation or dexamethasone-induced cell death of rat thymocytes. Biochem. Biophys. Res. Commun. 192: 386-391

24. Testolin L, Carson C, Wang Y, Walker PR, Armato U and Sikorska M (1997) Jun and JNK kinase are activated in thymocytes in response to VM26 and radiation but not glucocorticoids. Exp. Cell Res. 230: 220-232

25. Watabe M, Ito K, Masuda Y, Nakajo S and Nakaya K (1998) Activation of AP-1 is required for buffalin-induced apoptosis in human leukemia U937 cells. Oncogene 16: 779-787

26. Barry MA and Eastman A (1992) Endonuclease activation during apoptosis: the role of cytosolic $\mathrm{Ca}^{2+}$ and pH. Biochem. Biophys. Res. Commun. 186: 782-789

27. Collins MK, Furlong IJ, Ascaso R, Oliver J and Lopez Rivas A (1996) An apoptotic nuclease activated either by decreasing $\mathrm{pH}$ or by increasing calcium. J. Cell Sci. 109: $2393-2399$

28. Eastman A (1994) Deoxyribonuclease II in apoptosis and significance of intracellular acidification. Cell Death Differ. 1: 7-9

29. Eastman A (1995) Survival factors, intracellular signal transduction, and the activation of endonucleases in apoptosis. Semin. Cancer Biol. 6: 45-52

30. Gottlieb RA, Giesing HA, Engler RL and Babior BM (1995) The acid deoxyribonuclease of neutrophils: a possible participant in apoptosisassociated genome destruction. Blood 86: 2414-2418

31. Barry MA and Eastman A (1993) Identification of deoxyribonuclease II as an endonuclease involved in apoptosis. Arch. Biochem. Biophys. 300: 440-450

32. Nikonova LV, Beletsky JP and Umansky SR (1993) Properties of some nuclear nucleases of rat thymocytes and their changes in radiation-induced apoptosis. Eur. J. Biochem. 215: 893-901

33. Shiokawa D, Ohyama H, Yamada T, Takahashi K and Tanuma S (1994) Identification of an endonuclease responsible for apoptosis in rat thymocytes. Eur. J. Biochem. 226: 23-30

34. Harosh I, Binniger DM, Harris PV, Mezzina M and Boyd LB (1991) Mechanism of action of deoxyribonuclease II from human lymphoblasts. Eur. J. Biochem. 202 $479-484$.

35. Survachala E and Rao KS (1994). Purification and characterization of a deoxyribonuclease acting on nativeand UV irradiated DNA from young and aging brain. Mol. Cell. Biochem. 137: 109-116

36. Torriglia A, Chaudun E, Chany-FournierF, Jeanny J-C, Cuortois Y and Counis M$F$ (1995) Involvement of DNAse II in nuclear degeneration during lens cell differentiation. J. Biol. Chem. 270: 28579-28585

37. McGowan AJ, Fernandes RS, Verhaegen S and Cotter TG (1994) Zinc inhibits UV radiation-induced apoptosis but fails to prevent subsequent cell death. Int. J. Radiat. Biol. 66: 343-349
38. Yanagisawa-Shiota F, Sakagami H, Yashi NK, lida M, Sakagami T and Takeda M (1995) Endonuclease activity and induction of DNA fragmentation in human myelogenous leukemic cell lines. Anticancer Res. 15: 259-266

39. Famulski KS, Bashir S, Sikora E and Paterson MC (1997) Activation of a novel acidic endonuclease in apoptotic and proliferating cells. Proc. Am. Assoc. Cancer Res. 38: Abstract no. 3610

40. Yasuda T, Takeshita H, lida R, Nakajima T, Hosomi O, Nakashima Y and Kishi K (1998) Molecular cloning of the cDNA encoding human deoxyribonuclease II. J. Biol. Chem. 273: 2610-2616

41. Karin M, Liu ZG and Zandi E (1997) AP-1 function and regulation. Curr. Opin. Cell Biol. 9: 240-246

42. Wolf CM, Morana SJ and Eastman A (1997) Zinc inhibits apoptosis upstream of ICE/CED-3 proteases rather than at the level of an endonuclease. Cell Death Differ. 4: $125-129$

43. Hannun YA and Obeid LM (1995) Ceramide: an intracellular signal for apoptosis. TIBS 20: 73-77

44. Jarvis WD, Grant S and Kolesnick RN (1996) Ceramide and the induction of apoptosis. Clin. Cancer Res. 2: 1-6

45. Bierhaus A, Zhang Y, Quehenberger $P$, Luther T, Haase M, Muller M, Mackman N, Ziegler R and Nawroth PP (1997) The dietary pigment curcumin reduces endothelial tissue factor gene expression by inhibiting binding of AP- 1 to the DNA and activation of NF-kappa. B. Tromb. Haemost. 77: 772-782

46. Kuo ML, Huang TS and Lin JK (1996) Curcumin, an oxidant and anti-tumor promoter, induces apoptosis in human leukemia cells. Biochim. Biophys. Acta 1317: $95-100$

47. Arends MJ and Wyllie $\mathrm{AH}$ (1991) Apoptosis: mechanisms and roles in pathology. Int. Rev. Exp. Pathol. 32: 223-254

48. Zhivotovsky B, Wade D, Nicotera P and Orrenius S (1994) Role of nucleases in apoptosis. Int. Arch. Allergy Immunol. 105: 333-338

49. Cidlowski JA, King KL, Evans-Storms KL, Montague JW, Bortner CD and Hughes Jr FM (1996) The biochemistry and molecular biology of glucacorticoidinduced apoptosis in the immune system. Rec. Prog. Horm. Res. 51: 457-491

50. McConkey DJ and Orrenius S (1996) The role of calcium in the regulation of apoptosis. J. Leukocyte Biol. 59: 775-783

51. Khodarev NN and Ashwell JD (1996) An inducible lymphocyte nuclear $\mathrm{Ca}^{2+}$ $\mathrm{Mg}^{2+}$-dependent endonuclease associated with apoptosis. J. Immunol. 56: $922-931$

52. Deng GE and Podack ER (1995) Deoxyribonuclease induction in apoptotic cytotoxic T lymphocytes. FASEB J. 9: 665-669

53. Cigola E, Kajstura J, Li B and Anversa P (1997) Angiotensin II activates programmed myocyte cell death in vitro. Exp. Cell Res. 231: 363-371

54. Rauch F, Polzar B, Stephan H, Zanotti S, Paddenberg R and Mannherz HG (1997) Androgen ablation leads to an up-regulation and intranuclear accumulation of deoxyribonuclease I in rat prostate epithelial cells paralleling their apoptotic elimination. J. Cell Biol. 137: 909-923

55. Zhang G, Robertson MJ and Schlossman SF (1995) A triplet of nuclease porteins $\left(\mathrm{NP}^{42-50}\right)$ is activated in human Jurkat cells undergoing apoptosis. Cell. Immunol. 165: 161-167

56. Russo CA, Weber TK, Volpe CM, Stoler DL, Petrelli NJ, Rodriguez-Bigas M, Burhans WC and Anderson GR (1995) An anoxia inducible endonuclease and enhanced DNA breakage as contributors to genomic instability in cancer. Cancer Res. 55: 1122-1128

57. Anzai N, Kawabata H, Hirama T, Masunati H, Ueda Y, Yoshida Y and Okuma M (1995) Types of nuclear endonuclease activity capable of inducing nucleosomal DNA fragmentation are completely different between human $\mathrm{CD} 34^{+}$cells and their granulocytic descendants. Blood 86: 917-923

58. Enari M, Sakahira H, Yokoyama H, Okawa K, Iwamatsu A and Nagata S (1998) A caspase-activated DNAse that degrades DNA during apoptosis and its inhibitor ICAD. Nature 391: 43-50

59. Sakahira H, Enari M and Nagata S (1998) Cleveage of CAD inhibitor in CAD activation and DNA degradation during apoptosis. Nature 391: $96-99$

60. Piette J, Hirai S-I and Yaniv M (1988) Constitutive synthesis of activator factor protein 1 transcription factor afterviral transformation of mouse fibroblasts. Proc Natl. Acad. Sci. USA 85: $3401-3405$ 